\title{
Collagen Films Obtained from Collagen Solutions Characterized by Rheology
}

\begin{abstract}
SIMONA POPA ${ }^{1}$, SORINA BORAN ${ }^{1 *}$, VASILE SIMULESCU ${ }^{2}$
'Politehnica University Timisoara, Faculty of Industrial Chemistry and Environment Engineering, 6 Vasile Parvan,300223, Timisoara, Romania

Institute of Chemistry Timisoara of Romanian Academy, 24 Mihai Viteazul Blvd., 300223, Timisoara, Romania

Collagen is an important natural biopolymer, found in mammal's body. It is the main structural protein in the extracellular space in the various connective tissues. As the main component of connective tissue, it is the mostabundant protein in mammals. Its importance increased in last decades. Collagen has many applications in medicine and cosmetics. The work presented in this paper shows one method to obtain collagen films from collagen solutions. These collagen solutions were characterized by rheological measurements. The preparation of the collagen films was performed in the presence of calcium and silicium salts, using glycerin as plasticizer. The collagen was first solubilized and reconstituted, in order to maintain its initial properties.
\end{abstract}

Keywords: collagen solutions, collagen films, rheology, viscosity

The collagen structure from the animal skin is similar to the collagen found in the human's skin. Because of this reason, the collagen obtained from the animal skin can be used in medicine and cosmetics also [1-4].

The collagen protein is composed of a triple helix structure, which generally consists of two identical chains $(\alpha 1)$ and one additional chain that differs slightly in its chemical composition ( $\alpha 2)$. The amino acid composition of collagen is atypical for proteins. It has very high hydroxyproline content. The most common motifs in the amino acid sequence of collagen are glycine-proline- $X$ and glycine-X-hydroxyproline, where X could be any amino acid, except glycine, proline or hydroxyproline. The collagen can be obtained from the offal form the animal skin processing $[2,3]$.

In the form of elongated fibrils, collagen is mostly found in fibrous tissues (skin, tendons, and ligaments). Collagen is also abundant in other tissues, as corneas, cartilage, bones, blood vessels, intervertebral discs, dentin, and muscle tissues (collagen constitutes only $1-2 \%$ of muscle tissues) [1-5].

The fibroblast is the most common cell that creates collagen. Gelatin, which is used in food and industry, is hydrolyzed collagen (the hydrolysis reaction is in this case not reversible). As we mentioned before, because of its roles in the body, nowadays collagen has many medical uses and applications. It is used in treating complications of the bones and skin. It is one of the most important biopolymers from mammals' body [2-4].

The collagen should be solubilized and reconstituted in the presence of calcium and silicium salts, in order to obtain stable films. Calcium and silicium [6] ions allows the collagen reconstitution in vitro.

Because the collagen, as a natural biopolymer, has a high molar mass and high rigidity [7], the obtained solution will have a high viscosity, behaving as a viscoelastic material, which presents mixed properties of viscosity (as fluids do) and of elasticity (as solids do) [8].

The purpose of this paper is the obtaining the collagen solutions and their rheological characterization, and the preparation of the collagen films.

\section{Experimental part}

For these experiments the lime bathing gelatin leather splinter was used. The material was decalcified with $0.3 \%$ $\mathrm{HCl}$ and $0.8 \% \mathrm{NH}_{4} \mathrm{Cl}$ in $300 \%$ fleet. In order to make the product soluble it was previously treated with an alkaline solution, for $24 \mathrm{~h}$ at $20^{\circ} \mathrm{C}$, with $10 \% \mathrm{NaOH}$ and $1 \mathrm{M} \mathrm{Na} \mathrm{SO}_{2}$ in $300 \%$ fleet, and then the material was washed untit neutral $\mathrm{pH}$.

After that, it was solubilized with acetic acid 1.5M (75\% from the necessary amount) and then with acetic acid $0.5 \mathrm{M}$ (the rest of $25 \%$ of the necessary amount). The final $\mathrm{pH}$ of the collagen solution was around 3.5, having 3.6\% concentration.

The rheological behavior of collagen solutions with 0.8 ; $1.0 ; 1.5 ; 2.0 ; 2.5$ and $3.0 \%$ concentration in dry substance was determined at $22^{\circ} \mathrm{C}$ with a Brookfield CAP2000+L viscometer, according to ASTM D445.

All dilutions were made with acetic acid 0.5M.

\section{Results and discussions}

Rheology method was used to obtain the stable collagen films. Rheology is a technique which study of the flow of matter, primarily in a liquid state, but also as 'soft solids' or solids under conditions in which they respond with plastic flow rather than deforming elastically in response to an applied force [9-13,16-20]. It applies to substances which have a complex microstructure, such as muds, suspensions, polymers and other glass formers (silicates), as well as many foods and additives, bodily fluids (blood) and other biological materials or other materials which belong to the class of soft matter. [12,13,16-19]

It is well known that from the rheological behaviour, fluids may be divided into New tonian and non-Newtonian ones $[8,14,15]$.

The collagen solutions have a pseudoplastic behavior, which corresponds to the Ostwald de Waele rheological model $[8,15,21]$ :

where:

$$
\tau=K \cdot \gamma^{n}
$$

$\tau$ - cutting tension, dyne $/ \mathrm{cm}^{2}$

$\gamma$ - cutting speed, $\mathrm{s}^{-1}$

$\mathrm{K}$ - consistence coefficient

$\mathrm{n}$ - flow index, $\mathrm{n}<1$ 


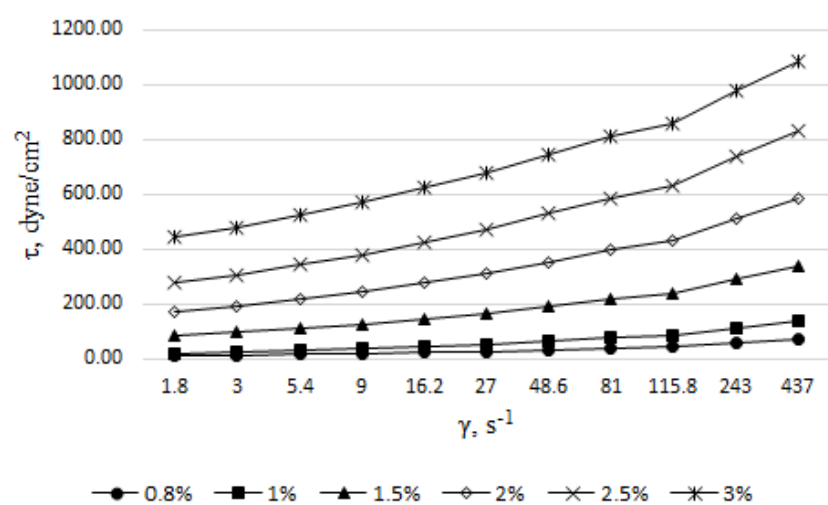

Fig.1. Variation of the cutting tension with the cutting speed at different collagen solution concentrations

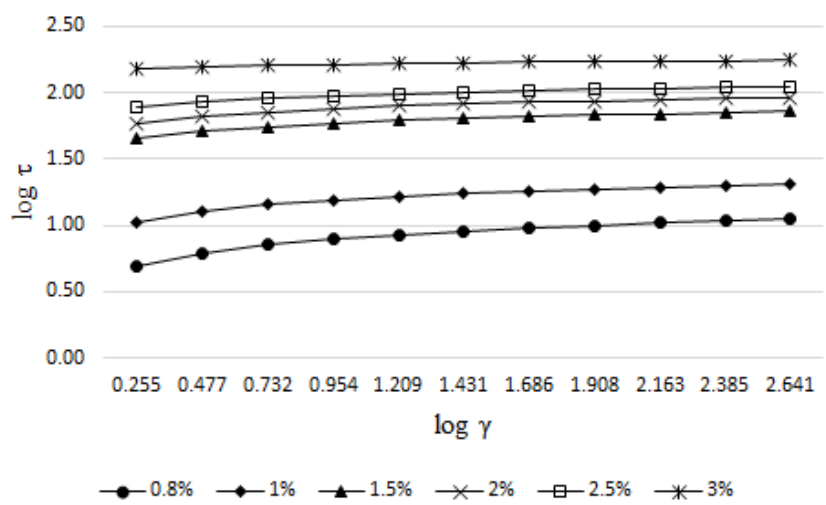

Fig.2. Logarithmic variation of the cutting tension with the cutting speed at different collagen solution concentrations

\begin{tabular}{|c|c|c|}
\hline Solutions concentration, c \% & $\mathrm{K}$ & $\mathrm{n}$ \\
\hline 0.8 & 7.95 & 0.351 \\
\hline 1.0 & 15.69 & 0.282 \\
\hline 1.5 & 59.01 & 0.203 \\
\hline 2.0 & 75.92 & 0.195 \\
\hline 2.5 & 94.85 & 0.158 \\
\hline 3.0 & 163.73 & 0.069 \\
\hline
\end{tabular}

Table 1

VALUES OF K AND $n$ PARAMETERS
To determine the values for $K$ and $n$ from the equation (1), the cutting speed was varied. Figure 1 presents the cutting tension variation with the cutting speed, at different concentrations of collagen solutions.

The rheological behavior of the pseudoplastic fluids can be explained by the instantaneous change of their structure through molecules slide depending on the tangential effort. If the effort gets down, their structure remakes [8]. The variation of the curves is similar to the non-Newtonian pseudoplastic fluids [15]. By increasing concentration, the cutting initial acceleration is more pregnant and the curves showed a shoulder (more visible athigher concentrations).

At the maximum cutting speed $\left(\gamma=437.4 \mathrm{~s}^{-1}\right)$ at low concentrations (1.5\%) the value of $\tau$ increases at small variations of concentration. When concentration is varied from 1.0 to $1.5 \%$ the cutting tension increases with around $1000 \mathrm{dyne} / \mathrm{cm}^{2}$. At higher concentration (2.5, 3.0 \%) there is practically no difference in $\tau$ values.

\begin{tabular}{|c|c|c|c|c|c|c|}
\hline & \multicolumn{6}{|c|}{$\eta^{-1} 10^{-3}[\mathrm{~Pa} . \mathrm{s}]$} \\
\hline & 0.8 & 1.0 & 1.5 & 2.0 & 2.5 & 3.0 \\
\hline 1.0 & 7.92 & 15.64 & 59.18 & 75.87 & 94.80 & 163.44 \\
\hline 2.0 & 5.43 & 10.35 & 36.39 & 46.91 & 57.61 & 94.33 \\
\hline 3.0 & 4.16 & 7.11 & 23.91 & 30.88 & 37.52 & 58.65 \\
\hline 5.0 & 2.78 & 4.68 & 14.83 & 19.45 & 22.82 & 33.87 \\
\hline 9.0 & 2.23 & 3.34 & 9.76 & 12.72 & 14.90 & 21.08 \\
\hline 16.5 & 1.45 & 2.32 & 6.21 & 8.00 & 9.22 & 12.33 \\
\hline 30.0 & 1.09 & 1.67 & 4.12 & 5.22 & 6.12 & 7.65 \\
\hline 50.5 & 0.81 & 1.06 & 2.52 & 3.39 & 3.77 & 4.43 \\
\hline 85.5 & 0.63 & 0.87 & 1.71 & 2.43 & 2.45 & 2.98 \\
\hline
\end{tabular}

Table 2

VALUES OF THE DYNAMIC VISCOSITY FOR THE COLLAGEN SOLUTION 
Finding the logarithm of equation (1), a new equation was obtained (2):

$$
\lg \tau=\lg K+\mathrm{n} \lg \gamma
$$

Representing the variation $\lg \tau=f(\lg \gamma)$ we obtained the dependencies from the figure 2 .

The values of $K$ and $n$ can be calculated from these dependencies. These obtained values of $K$ and $n$ are presented in table 1.

Table 2 presents the values of the dynamic viscosity for the collagen solution, calculated with the relation (3) [6]:

$$
\eta=K \cdot \gamma^{n-1}
$$

As it was previously mentioned in this paper, the collagen films were obtained in the presence of calcium and silicium salts, using glycerin as plasticizer ( $83 \%$ and $125 \%$ in dry substance). Different amounts of calcium acetate (1 $12 \%)$ and natrium silicates $(0.1-0.5 \mathrm{~mL})$ were added to the collagen solutions. The evaporation was realized in a forced air current at room temperature. The collagen films should be kept at a relative humidity of $65 \%$, for $24 h$, and then they may be used. Depending on the concentration of the ingredients, the elongation of the collagen film varied between 12 to $64 \%$.

\section{Conclusions}

The rheological behavior of the obtained collagen solutions was studied. The collagen films were prepared from these collagen solutions in the presence of calcium and silicium salts, using glycerin as plasticizer. Different amounts of calcium acetate and natrium silicates were also added to the collagen solutions. For collagen film preparation, the calcium and silicium salts could be also used together. The evaporation was realized at room temperature $\left(25^{\circ} \mathrm{C}\right)$.

One important observation is that at high glycerin amount, the elongation is bigger for all collagen films. The films with longer elongation have a small breaking resistance.

The offal utilization to recover the collagen from the animal skin is very important for medical purposes. The collagen has to be solubilized and then reconstituted in order to maintain its initial properties. The collagen solubilization has a real interest for theoretical studies as well as for practical purposes.

The collagen solution has a pseudoplastic nonNewtonian fluid behavior, which becomes more stressed with concentration increase. Collagen behaves as a tixotropic fluid. The driving resistance of the films is good at small amounts of calcium (above $10 \mathrm{~mL}$, the film rigidity increased). The optimal driving resistance was obtained when adding $83 \%$ glycerin (in dry substance).

\section{References}

1.LULLO, D., SWEENEY, A.G., SHAW N, M., KORKKO, J ., ALA-KOKKO, L., SAN ANTONIO, J., J. Biol. Chem., 277, no. 6, 2002, p. 4223

2.ZDZISLAW, E.S., Chemical and Functional Properties of Food Proteins. Boca Raton: CRC Press., 2001, p. 242

3.SZPAK, P., J ournal of Archaeological Science, 38, no. 12, 2011,

p. 3358

4.DIEGELMANN, R., Medscape.com. Medscape, 2014

5.GORRES, K.L., RAINES, R.T., Crit. Rev. Biochem. Mol. Biol., 45, no. 2, 2010, p. 106

6.VORONKOV, M., ZELCIAN, G., LUKEVIT, E., Siliciul si viata, Ed. Stiintifica, Bucuresti 1974, p.145

7.CHIRITA, G., BOIERU, C.I., Bazele fabricarii pieilor, Ed.Tehnica, Bucuresti 1975, p. 253

8.BRATU, E.A., Operatii unitare in ingineria chimica, vol I, Ed.Tehnica, Bucuresti 1984, p. 293

9.DEIBER, J.A., PEIROTTI, M.B., OTTONE, M.L., Food Hydrocolloids, 25, no. 5, 2011, p. 1382

10.DUAN, L., JIHENG, L., CONGHU, L., GUOYING, L., Korea-Australia Rheology Journal, 25, no. 3, 2013, p. 137

11.YANG, Y., KAUFMAN, L.J ., Biophysical J ournal, 96, 2009, p. 1566

12.COLLYER, A.A., CLEGG, D.W., Rheological Measurement, Springer Science \& Business Media, 2012

13.COLLYER, A.A., Techniques in Rheological, Measurement Springer Science \& Business Media, 2012.

14.TUDOSE, R., Procese si utilaje in industria de prelucrare a compusilor macromoleculari, Ed.Tehnica, Bucuresti 1976, p. 165

15.PETREA, I.C., IONESCU, L., Fizica elastomerilor. Reologie, Ed. Didactica si Pedagogica Bucuresti, 1981, p.158

16.NISHAD FATHIMA, N., DHATHATHREYAN, A., RAMASAMI, T., KRÄGEL, J., MILLER, R., International J ournal of Biological Macromolecules, 48, 2011, p. 67

17.AREVALO, R.C., URBACH, S.J., BLAIR, D.L., Biophys J. 2010, 99, no. 8, p. 65

18.ZHANG, M., YIHUI, C., GUOYING, L., ZONGLIANG, D., Korea-Australia Rheology Journal, 22, 2010, p. 119

19.SCHOWALTER, W.R., Mechanics of Non-Newtonian Fluids Pergamon, 1978

20.KOHN, D., SORA, M., PODE, V., Fenomene de transfer si utilaje în industria chimica, vol. I, Ed.U.P.T. 1993, p. 21

21.BORAN, S., POPA, S., JURCAU, D., Rheological study on fatty acid polyesters produced using nanotechnologies, 1st International Conference on Bioresource Technology for Bioenergy, Bioproducts \& Environmental Sustainability, 23-26 October 2016, Sitges, Barcelona, Spain

Manuscript received: 14.12 .2016 